\title{
Determinant Factors Affecting the Implementation and Socio- Economic Impact of Waste Bank Policy in Makassar City
}

\author{
Muhamad Jusman ${ }^{1}, \operatorname{Armin}^{1}$, Nur Indrayati Nur Indar ${ }^{1}$ \\ ${ }^{1}$ Public Administration, Faculty of Social and Political Sciences, Hasanuddin University, \\ Indonesia
}

\begin{abstract}
This paper discusses the Determinant Factors Affecting the Implementation and SocioEconomic Impact of the Waste Bank Policy in Makassar City. This research method uses this type of research, namely descriptive qualitative. Several methods of data collection carried out are Interview, Observation and documentation. The results of the study indicate that this central Waste Bank has an obligation to pick up and purchase waste. because so far, the Waste Banks that have been formed have collided in the pick-up and purchase areas of waste, so that the Central Garbage Bank is the answer to the problems that have been programmed by the Waste Bank. The average condition of landfills in Indonesia, including Makassar City, is no longer able to accommodate waste and will cause social problems. The economic function of the waste bank is to give a high value to the waste which was originally considered low, does not mean anything and is a big problem and burden for the government and its people.
\end{abstract}

Keywords: Policy Implementation, Socio-Economic Impact, Waste Bank

Received: August 3, 2021

Revised: September 5, 2021

Accepted: September 12, 2021

\section{Introduction}

Garbage Banks in general are almost the same as other banks, there are customers, employees, bookkeeping and management. The place or location of the Waste Bank can be in the form of open land, warehouses and vacant lands that can accommodate large amounts of waste. Meanwhile, customers of the Waste Bank are individuals, communities/groups who are interested in saving their waste in the Waste Bank. Individuals are usually representatives of the household heads who collect household waste. The way to save at the Waste Bank is that every customer registers with the manager, the manager will record the customer's name and each member will be given an official savings book (Poongodi et al., 2020).

The Makassar City Government takes the formation of a Waste Bank very seriously, so that the Makassar City Mayor Regulation No. 126 of 2016, concerning the Establishment, Position, Organizational Structure, Job Description and Work Procedures of the Waste Bank Technical Implementation Unit has been issued at the Environmental Service. Based on this, the spearhead of Waste Bank management in Makassar City is the Waste Bank Technical Implementation Unit (UPT) at the Environmental Service.

Garbage Banks in Makassar City have now been running for approximately 5 years, actually since 2011, but have not been implemented properly due to various obstacles/problems faced so that they are effective in 2015, and 600 units of Waste Banks have been formed, with the number of customers reaching more less than 50 thousand people. Waste Banks are scattered throughout RT/RW, in schools and in government agencies (Ailah \& Ridwan, 2019).

Since 2015 until now (2019) the Waste Banks in Makassar City have increased, namely around 1000 Waste Banks spread throughout Makassar City and have succeeded in reducing waste production which was originally 1,200 tons per day in 2018 to 900 tons per day in 2019 . 
The Waste Bank Policy in Makassar City, as mandated by the Law and the Mayor of Makassar City Number 126 of 2016, Article 5 that the Tasks of the Garbage Bank UPT has not been fully implemented, has not completely solved the waste problem. Of the total waste products of 1,200 tons per day, only 300 tons do not reach the landfill, while the remaining 900 tons per day accumulate in the landfill, meaning an increase compared to 2018 which was 700-800 tons per day. Garbage managed by the Waste Bank is Non-Organic Waste, and is still being sorted out for proper deposit in the Waste Bank, so that waste such as used goods, inappropriate plastic bottles and cups and organic waste are still found in various places, especially in public areas. and sewers.

The Waste Bank's policy which entices to sort waste, maximize the use of used goods, instill understanding and reduce the amount of used goods that is wasted, is quite useful because it has economic value, reduces the amount of waste to the landfill and maintains cleanliness. But this hope is not evenly distributed across all levels of society. This policy only touches lowincome groups. Collecting, sorting and reselling waste is considered a futile job, a job that requires energy and time while the results are far from the expectations of those from the middle to upper economic class (ANAS, 2019).

The implementation of the Waste Bank Policy in Makassar City is a top down implementation model. The top down model suggests that policy makers are the only important actors so that actors at the organizational/lower level are only tasked with carrying out the implementation process.

The top-down implementation model contains the idea that implementation is making people do what they are told and controlling the sequence of stages in a system (Lao et al., 2008).Top down model or bottom up model, fails to provide a comprehensive synthesis or an integrated approach to implementation analysis and tends to ignore the network nature of policy implementation (Matland et al., 1995). Based on this kind of thinking, the main problems in this research are: How is the Implementation Model, Determinant Factors and Social/Economic Impacts of the Waste Bank Policy Implementation Model in Makassar City

\section{Methods}

The type of this research is descriptive qualitative, which is to describe the existing secondary data, both from literature, library data and other documents, then research in the field by focusing this research on the Main Waste Bank (BSI) of Makassar City. The Makassar City Waste Bank (BSI) is located at Jalan. Todopuli Raya Timur, is the sole parent of all Garbage Banks in the city of Makassar. The Main Waste Bank which was established in 2014, based on Perwali Number: 63 of 2014, concerning the Establishment of a Regional Technical Implementation Unit (UPTD) for Waste Recycling Management. describe and explain the Waste Bank Policy Implementation Model in Makassar City.

Determinant Factors Affecting the Implementation of Waste Bank Policy; includes Policy Accuracy, namely the extent to which policies solve problems, Implementation Accuracy, namely actors who carry out government, private or private policies, Target Accuracy, namely in accordance with plans, readiness, Environmental Accuracy, namely: Interaction between formulating institutions and policy implementers, public opinion, interpretation of strategic institutions, the individual who plays the role. The social/economic impacts of implementing the Waste Bank policy include; The positive impact; people can interact, get to know each other so that cooperation is established. Economic impacts include; People get new jobs so that they can increase their income to meet their needs. 
Several methods of data collection carried out are Interview, Observation and documentation. The data collected from the interviews will be combined with data from observations and data from other written documents to be processed in a qualitative descriptive manner

\section{Results and Discussion}

\section{Determinant Factors Affecting the Implementation of Waste Bank Policy in Makassar City}

The Waste Bank Program in Makassar City itself has been running since 2015, namely since the launch of the Makassar City Center Waste Bank by the Mayor of Makassar, 2014-2019 Period.

The central waste bank has a very central role, where the central waste bank has the obligation to pick up and buy waste. because so far the Waste Banks that have been formed have collided in the pick-up and purchase areas of waste, so that the Central Garbage Bank is the answer to the problems that have been programmed by the Waste Bank.

The Central Waste Bank itself has to work extra hard so that the waste in the Waste Bank Unit can be purchased, because there is little difference between the Waste Bank and the collectors. Waste Banks buy various types of waste, especially inorganic waste, while collectors only buy 1-3 types of waste.

The Central Waste Bank itself in its operations has found the right way to solve this problem. What has been done so far is only for the community, because we know together with the government without the support of the community, especially the Waste Bank program, it will not run as well as it is today.

The Central Waste Bank is a regional agency authorized to facilitate the establishment and management of a Waste Bank Unit (BSU) in Makassar City, which in turn becomes a partner of the Central Garbage Bank UPT in managing waste by implementing the 3R system and making waste have economic value. The Unit Waste Bank (BSU) is managed by the community, both at the level of the Neighborhood Unit (RW/RT) and at the Kelurahan level. At BSU, waste is collected and sorted according to its type and managed using a banking-like system by providing savings books to customers. The waste saved by the community will be weighed and rewarded at a price set by the BSU management. The results from the collection of waste at the BSU are then sold to the UPT of the Main Garbage Bank of Makassar City.

\section{Waste Management}

Organic waste management activities start from households collecting waste from their daily activities, sorting, bringing it to the BSU, weighing and so on (Aja \& Al-Kayiem, 2014). Various recycling systems can be applied, because the composition of the largest waste in cities in Indonesia, including Makassar, is mostly organic waste, so an individual, communal, regional scale composting system is introduced, both for high groundwater areas (wet areas) and for low groundwater. Meanwhile, for the reuse of both organic and inorganic waste, examples that can be applied and the introduction of Waste Banks are introduced. For waste reduction, simple techniques are introduced such as reducing packaging, reverting to degradable packaging. For this reason, the 3R system of waste management (reuse, reuse, recycle), through collection, sorting, and community waste management must be continuously encouraged.

\section{Community-Based 3R (reduce, reuse, recycle) Waste Management system}

The 3R waste management approach opens new views and insights for the community in managing waste. Waste is no longer seen as useless, but through the $3 \mathrm{R}$ approach, waste can 
be used as something of added value. 3R is an effort that includes activities to reduce (reduce), reuse (reuse) and recycle waste (recycle).

$\mathrm{R} 1$, is an effort that focuses more on reducing consumptive lifestyles and always uses "nondisposable" which is environmentally friendly and prevents waste generation,

$\mathrm{R} 2$, is an effort to utilize waste materials through repeated use so that they do not immediately become waste, without processing means reusing waste that is fit for use for the same or other functions.

R3, After the waste has to leave the home environment, it is necessary to sort and utilize local processing into new products. Waste management with the $3 \mathrm{R}$ pattern is an effort to reduce the burden of the TPA (final processing site) for waste.

Implementation of 3R The government and local governments are required to do the following: (1) Set a target for reducing waste gradually within a certain time; (2) Facilitate the application of environmentally friendly technologies; (3) facilitate the application of environmentally friendly product labels; (4) facilitate reusing and recycling activities and; (5) facilitate the marketing of recycled products

Operational techniques for waste management starting from the source of the waste to the final processing, the $3 \mathrm{R}$ program needs to be implemented as much as possible at the source as shown in Figure 1.

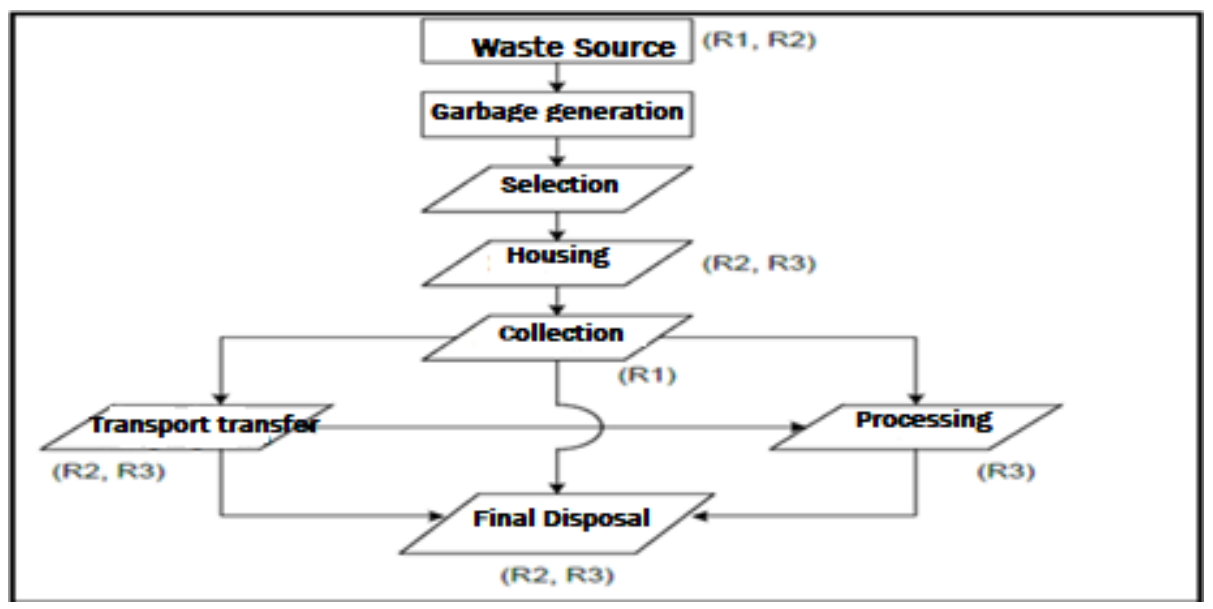

Figure 1. Operational Techniques

\section{Waste management in the Waste Bank}

\section{Household Waste Segregation}

The customer must sort the waste before it is deposited into the Waste Bank. Waste segregation depends on the agreement at the time of the formation of the Waste Bank (Kahhat et al., 2008). For example, based on the category of organic and inorganic waste. Usually the inorganic waste is then separated again based on the type of material; plastic, paper, glass and others. Garbage grouping will facilitate the process of distributing waste (Dutt \& King, 2014). Will it be delivered to the composting site, plastic factory or home industry.

With the Garbage Bank system, the community has indirectly helped reduce the accumulation of waste in landfills. Because most of the waste that has been sorted and sent to the Waste Bank will be reused, so that what is left and disposed of to the TPA is only waste that has no economic value and B3 waste. 


\section{Garbage deposit to Garbage Bank}

Garbage deposit time is usually agreed in advance. For example, two days a week every Wednesday and Saturday. This scheduling is intended to equalize the time customers make deposits and transportation to collectors (Ganji et al., 2021). This is so as not to pile up at the Waste Bank location.

\section{Weighing}

The waste that has been deposited in the Waste Bank is then weighed. The weight of waste that can be deposited has been determined in the previous agreement, for example, it must be at least one kilogram.

\section{Recording}

The officer will record the type and weight of the waste after weighing. The measurement results are then converted into rupiah values which are then written in the savings book. In the Waste Bank system, savings can usually be withdrawn every three months (Wulandari, 2019). Waste Bank Savings can be modified into several types; holiday savings, education savings and social savings to be channeled through social institutions. At this stage, customers will feel the benefits of the Waste Bank system. By setting aside a little energy to sort out the garbage. People will benefit in the form of savings. With a "conventional" waste management system, people actually have to spend money, paying cleaners to manage waste.

\section{Freight}

The Waste Bank has collaborated with collectors who have been appointed and agreed upon. So that after the waste is collected, weighed and recorded, it is immediately transported to the next waste processing site. So, garbage does not pile up at the Waste Bank location. Waste Banks can develop into a source of raw materials for home industries around the Bank's location (Henry et al., 2006). So, waste processing can be done by people who are also customers of the Bank. Thus, the public can get double benefits from the Waste Bank system, namely savings and profits from the sale of products made from recycled materials.

\section{Socio-Economic Impact of the Implementation of Waste Bank Policy in Makassar City}

If waste management is not carried out in a systematic, comprehensive, and sustainable manner, it will cause various negative impacts. These impacts are as follows: (1) Impact on health: a breeding ground for organisms that can cause various diseases, poison animals and plants that are consumed by humans; (2) Impact on the environment: death or extinction of flora and fauna as well as causing damage to natural elements such as coral reefs, soil, waters to the ozone layer; (3) Socio-economic impacts: causing bad smells, bad views which also have a negative impact on tourism as well as disasters, such as floods.

\section{Social Impact}

The presence of the Waste Bank is to reduce waste that goes to the Final Disposal Site (TPA). Because the average condition of landfills in Indonesia, including Makassar City, is no longer able to accommodate waste and will cause social problems. The Waste Bank in Makassar city is expected to be a space for interaction, friendship, getting to know each other, for all residents of the neighborhood where the waste bank is located. So that the community will feel that they have and care for each other which will ultimately create a safe and conducive environment.

\section{Economic Impact}

The economic function of the waste bank is to give a high value to the waste which was originally considered low, does not mean anything and is a big problem and burden for the 
government and its people. However, with the Waste Bank, waste is no longer a burden but can be seen as a gift because of the selling value it has. Waste Banks can also be present as new jobs for the community. With the presence of the Garbage Bank, the community can join as administrators of the Waste Bank or customers who can have a lot of income

\section{Conclusion}

The central waste bank has a very central role, where the central waste bank has the obligation to pick up and buy waste. because so far the Waste Banks that have been formed have collided in the pick-up and purchase areas of waste, so that the Central Garbage Bank is the answer to the problems that have been programmed by the Waste Bank. The average condition of landfills in Indonesia, including Makassar City, is no longer able to accommodate waste and will cause social problems. The economic function of the waste bank is to give a high value to the waste which was originally considered low, does not mean anything and is a big problem and burden for the government and its people.

\section{References}

Ailah, M., \& Ridwan, M. (2019). Aktualisasi Makna Al-Tuhuru Shatru Al-Iman Melalui Bank Sampah Dalam Meningkatkan Kesehatan Lingkungan. Jurnal Ilmiah Mahasiswa Raushan Fikr, 8(1), 63-82.

Aja, O. C., \& Al-Kayiem, H. H. (2014). Review of municipal solid waste management options in Malaysia, with an emphasis on sustainable waste-to-energy options. Journal of material cycles and waste management, 16(4), 693-710.

ANAS, A. R. (2019). PROSEDUR PENGADAAN BARANG IMPOR PAPER KRAFT MILIK PT. SEMEN INDONESIA CABANG TUBAN. KARYA TULIS.

Dutt, N., \& King, A. A. (2014). The judgment of garbage: End-of-pipe treatment and waste reduction. Management Science, 60(7), 1812-1828.

Ganji, M., Rabet, R., \& Sajadi, S. M. (2021). A new coordinating model for green supply chain and batch delivery scheduling with satisfaction customers. Environment, Development and Sustainability, 1-36.

Henry, R. K., Yongsheng, Z., \& Jun, D. (2006). Municipal solid waste management challenges in developing countries-Kenyan case study. Waste management, 26(1), 92-100.

Kahhat, R., Kim, J., Xu, M., Allenby, B., Williams, E., \& Zhang, P. (2008). Exploring e-waste management systems in the United States. Resources, conservation and recycling, 52(7), 955-964.

Lao, O., Lu, T. T., Nothnagel, M., Junge, O., Freitag-Wolf, S., Caliebe, A., ... \& Kayser, M. (2008). Correlation between genetic and geographic structure in Europe. Current Biology, 18(16), 1241-1248.

Matland, R. E. (1995). Synthesizing the implementation literature: The ambiguity-conflict model of policy implementation. Journal of public administration research and theory, 5(2), 145-174.

Poongodi, M., Hamdi, M., Vijayakumar, V., Rawal, B. S., \& Maode, M. (2020, September). An effective electronic waste management solution based on blockchain smart contract in 5G communities. In 2020 IEEE 3rd 5G World Forum (5GWF) (pp. 1-6). IEEE.

Wulandari, Y. (2019). THE IMPACT OF WASTE MANAGEMENT ON THE IMPROVEMENT OF ISLAMIC ETHICS OF MADIUN SOCIETY (Doctoral dissertation, UNIDA). 